\title{
THE PAUL CF HISTORY AND THE APOSTLE OF FAITH
}

By N. T. W!right

'Controversy' writes Ernst Käsemann 'is the breath of life to a German theologian':/1/ and he should know. What he imagines the rest of us breathe he does not say: but since the essay which begins with these words engages in debate with Krister Stendahl, a Swede now living in America, I see no reason why a mere Englishman may not join in as well. I want in this lecture to contribute to the debate in question, and then to exploit the ambiguities of my title and discuss the distinction which needs to be made today between the real Faul and the Apostle of the church's imagination. The debate between Stendahl and Käsemann concerns the relation, in Paul's thought, between justification and salvationhistory - between the Apostle who preached the Lutheran cospel of justification by faith and the Paul who was called, in God's historical purposes, to be the Apostle to the centiles. It would not be an overstatement to say that all the major issues in Pauline interpretation are contained (at least by implication) in this debate, and in one lecture there are therefore bound to be oversimrlifications and downright lacunae. I want to try nevertheless to present what I take to be a new view of Paul, in the hope of at least stimulating fresh thought, and also to prepare the way for further, and fuller, exegetical stucies. If I seem at times to be deliberatel controversial, I hope you will take that as a sign that I an trying to impart the breath of life to the subject.

* Delivered at Tyndale House, Cambridge, on 4th July, 1978.

1. Ferspectives on Paul (hereafter Pr), ET of. raulinische Perspektiven, J. C. B. Mohr (Paul Siebeck), Ț̈̈bingen (1969), SCM, London (1971) 60. 
I Justification and Salvation History: Stendahl and Käsemann

I begin, then, with the debate between Stendahl and Käsemann. Nearly 20 years ago Krister Stendahl wrote the now famous article 'The Apostle Paul and the Introspective Conscience of the West'./2/ In it he pleaded that we should let the text which Paul actually wrote function as a critique of inherited presuppositions in interpretation, and warned of the danger of 'modernizing' Paul. Specifically, he claimed that the picture of Paul inherited from Augustine and Luther was misleading in several important respects. Paul, he said, had never suffered from a bad conscience: the soul-searchings and agonies of Luther were not to be read back into Romans or Galatians. Instead of the question 'how can I find a gracious God God?', Paul had asked the question: granted that the gospel is for the Gentiles, what is now the place of the Jews, and of the Torah? Romans 9-11 is, he claimed, the real centre of the epistle: salvation-history is the basic content of Paul's theology, and justification by faith is part of Paul's apologetic for the Gentile mission and the place of Gentiles in the church.

Not surprisingly, this drew a sharp intake of the breath of life from Ernst Käsemann./3/ Salvation-history, he affirmed, was opposed to the true Protestant doctrine of justification and its basis, the theologia crucis. The gospel of the cross shatters comfortable assumptions, and declares, particularly to those who rest on their historical background and continuity with the past, that God is the God who justifies the ungodly. Though Käsemann, like Stendahl, insists that the Bible must be allowed to be over the church, he does not tackle the detailed exegetical points on which stendahl had based

2. The article, first published in HTR 56 (1963) 199215, and reprinted now in Paul Among Jews and Gentiles, SCM, London (1976) 78-96, developed from an article in Svensk Exegetisk Arsbok 25 (1960) 62-77.

3. 'Justification and Salvation History in the Epistle to the Romans', $P P$ 60-78. 
much of his case, but leans heavily on a theological interpretation of twentieth-century politics and philosophy, warning that salvation history had been used to back up Nazism, and aligning it withn'an immanent evolutionary process whose mearing can be grasped on earth, or which we can control or calculate'./4/ While agreeing that there is a sense in which, 'for Paul, Christianity is in continuity with Judaism, Käsemann emphasizes the discontinuity. Though justification and salvation history belong together, justification is prior in every sense. Otherwise, says Käsemann, we cease to be true Protestants.

Stendahl has now replied to Käsemann, in the book which reprints his original essay./5/ He claims, justifiably, that Käsemann has misrepresented him at various points, and questions whether 'the justification of the ungodly', being mentioned so rarely by Paul, can properly be regarded as the centre of his thought. Käsemann, he says, has begged the question by beginning from the traditional Protestant doctrine of justification which it was his (Stendahl's) purpose to challenge. Whereas Käsemann claims that justification is 'the centre the beginning and the end of salvation history' $/ 6 /$ stendahl re-asserts that 'the very argument about justification by faith functions within [Paul's] reflection on God's plan for the world', and he points out tartly that, if theologies of history have been responsible for political evils in Germany, so has a theology which has seen 'the Jew' as the symbol of all that is false and dangerous in religion.

The last point is one of the most important that the debate has raised. I will shortly question very seriously whether the traditional understanding of Judaism and of Paul's attack on it is not fundamentally mistaken. And stendahl is absolutely right to draw attention to Paul's robust conscience, and to the fact that justification and salvation history have a habit of keeping cl.ose company in Paul (Romans 1-4, 9-11, Galatians 2-4, Philippians 3). It does appear that

4. Ibid. 63 .

5. Paul Among Jews and Gentiles (hereafter PJG) 129-33.

6. PP 76. 
Käsemann has not allowed for the force of these arguments, themselves (we should note) essentially historically-critical ones, essentially a critique of presuppositions on the basis of the text, and has on the contrary lapsed into a dogmatic polemic which does little credit to his professed desire to let the church stand under the word. Nevertheless, many of his criticisms strike home at stendahl: the scheme the swede has proposed has little or no place for the theology of the cross, for the discontinuity between Christianity and Judaism witnessed to by Paul's strong polemic in Romans, Galatians and Philippians; for the contrast between Adam and Christ, or for the fact that it is salvation, salvation from sin and ungodliness, that paul is talking about. Käsemann, in fact, is not alone in leaning heavily on twentieth century dogmatic presuppositions, though he does so more openly. Stendahl's belief that Jews have their own way of salvation apart from Christ and the church/7/ has clearly in turn influenced his reading of the text. It is curious how, though both men have reacted sharply against Nazism and anti-Semitism, they have arrived at opposite conclusions.

This debate has all the makings of a classic, with the agenda including wide-ranging issues in Pauline theology, detailed exegesis of several passages, and challenges to traditional dogmatic frameworks, all with inescapable twentieth-century overtones. I want now to contribute to it by offering a new way of locking at Paul which provides, I believe, not only an advance in the debate between Stendahl and käsemann but also a new perspective on other related pauline problems. I shall first slietch out this new view and argue briefly for its central thrust, and then show how it offers new light on the debate. That will be the first half of the lecture, and will provide the groundwork for the (shorter) second half, in which I will try to distinguish the Paul of history from the Apostle of traditional imagination.

7. PJG 132. See the critique of Stendahl in $W . S$. Campbell, 'Paul Among Jews and Gentiles. Krister Stendahl and Paul's Letter to the Romans' in the forthcoming proceedings of the 1978 Oxford Congress on Biblical studies. 
One of the central points in the view I propose is that Paul regarded the historical people of Abraham as God's answer to the problem of the sin of Adam. He would have agreed in principle with the Rabbi who put into God's mouth the words 'I will make Adam first: if he goes wrong Abraham will come to restore everything again'./8/ Romans 4 and Galatians 3 are best explained not as arbitrary proofs of justification by faith but as an exposition of the true nature of Abraham's faith and his family. Paul, in other words, read Genesis 12ff. as the sequel to Genesis 1-11. Where Paul differs from Jewish understanding, however, is in the next step of the argument: Abraham's people, intended as a light to the world, provided only darkness. Israel, as Psalm 8 implies,/9/ were meant to be God's new humanity, taking Adam's place under God in obedience and over the world in authority, but Israel failed in this task. Their failure - whose nature I shall come to in a moment meant both that the task had to be undertaken by their representative, alone, and also that they would themselves need saving. By acting out on a grand scale the sin of Adam,/10/ Israel not only could not redeem the world, but also needed redeeming herself.

If we ask how it is that Israel has missed her vocation, Paul's answer is that she is guilty not of 'legalism' or 'works-righteousness' but of what I call 'national righteousness', the belief that fleshly Jewish descent guarantees membership of God's true covenant people. This charge is worked out in Romans 2:17-29, 9:30-10:13, Galatians, and Philippians 3 , to which we will return later. Within this 'national righteousness', the law functions not as a legalist's ladder but as a charter of national privilege, so that, for the Jew, possession of the law is three parts of salvation: and circumcision functions not as a ritualist's outward show but as a badge of national privilege. Over against this abuse of Israel's undoubted privileged status, Paul establishes, in his theology and in his missionary work, the true children of Abraham, the world-wide community of faith. Faith, unlike the Torah, is available to all.

\footnotetext{
8. Gen. R. 14:6: cf. $S B$ J.II, 478, 597.

9. Cf. C. F. D. Moule, The Origin of Christology, Cambridge University Press (1977) 152.

10. Rom. 5:20 with 5:12: compare Rom. 11:11-15.
} 
At the centre of this scheme of thought stands Christology, since the task of Israel has now been handed on by default to Israel's anointed representative, the Messiah. Two aspects of Christology in particular stand out here. First, the Messiah sums up his people in himself, so that what is true of him is true of them. Second, the Messiah has died and been raised. From these two sources flow salvation history and justification by faith, not as two parallel streams, nor even as two currents in the same stream, but as one stream. If the Messiah has died and been raised, so has Israel: and her death and resurrection consist precisely in this, that God's purpose of saving Jews and Gentiles alike is achieved through justification, in Christ, by faith. And behind the Christology and the soteriology stands the theology: there is one way of justification for all men (Romans 3:27ff.) since God is one. In a brilliant and daring move, Paul takes the Shema itself, the heart of Jewish life and worship, and uses it as the heart of justification and salvation history, which are as inseparable in Romans 3 as anywhere else./11/ The one God has purposed and promised that he will create one worldwide family for Abraham, a family in whom the sin of Adam is reversed: and this he has achieved in the Messiah, Jesus.

The fundamental assumption behind this view, that the Messiah sums up his people in himself, is not (of course) new, /12/ but is so often ignored or overlooked that it is worth rehearsing in brief some of the arguments for it. In his picture of Jesus Christ Paul uses several themes - 'Son of David, Son of God, the Spirit, the resurrection, and so on - which combine to make the Messiah, in OT terms, the representative of Israel, the representative (on the one hand) of fleshly Israel, with whom he is identified according to the flesh (Romans 9:5), and the representative (on the other hand) of the true Israel, the worldwide people of God. In Romans 1:3f。 in particular, which can be shown to be programmatic for

11. This has already been noted in a forthcoming article by G. B. Caird.

12. Compare, e.g., N. A. Dahl, Das Volk Gottes, Jacob Dybwad, Oslo (1941), 227: G. B. Caird, 'Paul's Theology', $H D B^{2}$, cols. 738-9. 
the epistle as a whole, the 'Son of David' motif points back to 2 Samuel 7:14ff.,/13/ to the son of David who will be called the son of God, even as Israel is called the son of God in the exodus narrative and elsewhere. /14/ But David's son as God's anointed carries in the old Testament even stronger implications of identity with the people. In 2 samuel 5:lff. the tribes of Israel come to David at Hebron and say 'behold, we are your bone and your flesh': and, thus claiming him as their king, they anoint him./15/ The anointed one is the one in whom, according to the flesh, Israel is summed up: and Paul is (I suggest) deliberately evoking this old Testament background in Romans 1:3 and 9:5, both of which are programmatic. The Messiah as David's son according to the flesh, and as the son of God, embodies Israel in himself.

Once we recognise this point we can see it all over the New Testament, not least in the gospel presentation of Jesus as the Son of Man, taking on himself the role of suffering Israel, dying frecisely as the King of the Jews./16/ It is reflected specially in Paul's use of the word itself. While this may well have become a proper name in many of its occurrences, its titular use is at least never far away, and emerges in the well-

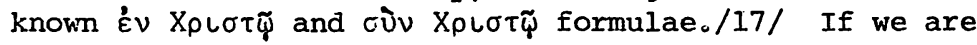

13. M. Hengel, The Son of God, SCM, London (1975) 64, and the literature there cited.

14. Ex. 4:22: cf. Dt. 14:1, Je. 31:9, Ho. $11: 1$.

15. Cf. too Jdg. $9: 2,2 \mathrm{Sa} .19: 12,13$. Compare also, for the wider OT background, Ps. 2:2, 18:50, 20:6, $45: 7,89: 20,38,51$, Isa. 61:1, and particularly Isa. $11:$ fff. See too the discussions in Hengel, op: cit. 61, Houle, op. cit. 31-35, 47-96, and W. C. van Unnik, 'Jesus the Christ', NTS 8 (1961-2) 101-16.

16. Cf., e.g., $\mathrm{K}, \mathrm{H}$. Rengstorf in The New International Dictionary of New Testament Theology, ed. C. Brown, vol. 2, Faternoster, Exeter (1976), 334-43, here at 339 .

17. For details, cf. TDNT 9, 540-62 (W. Grundmann), and Moule, op. cit. 54-69. 
right, those phrases mean primarily 'belonging to the people of the Messiah' or 'members of Israel' in a way which cannot be reduced either to talk of 'fields of force $/ 18 /$ or to the experience of Christian community. /19/ They refer to the visible, historical people of God. This is brought out strikingly in some of the

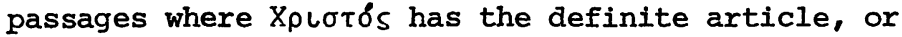
where the genitive $Y_{\rho} \iota \sigma \tau 0 \sigma$ is used. We may note, for instance, 1 Corinthians $1: 12 \mathrm{ff}$., where the visible church is clearly the context, and Galatians 3:29, where baptism into Christ, belonging to the Messiah, justification by faith, and membership in Abraham's worldwide family are closely and fascinatingly correlated. The Messiah's people, like Moses' people in 1 Corinthians 10, are a visible community entered by a real (and not a metaphorical) passage through water. $120 /$.

One of the strongest arguments for the identification of the Messiah with his people, and one of the best ways of seeing its effects in both justification and salvation history, is the fact that the cross was a stumbling block, a scandal, to the Jews. This cannot be reduced to general terms of the offence of the cross, as though the distinction stated in 1 Corinthians 1:23 was merely rhetorical. The cross is offensive to Jews because a crucified Messiah implies a crucified Israel. Israel rejects the proffered Messiah precisely because she understands this: that is part at least of the force of Romans 9:33. If the Messiah dies under the law's curse, that means that Israel stands under the same curse: that is -part at least of the meaning of Galatians 3:10-14. Calvary means that Israel also must die between two thieves, must share the fate of the ungodly. In the long purposes of God, Israel acts out the role of fallen mankind. Nor does she thus escape from fulfilling also the role for which God has cast her, since it is precisely by her fall that salvation is brought to the Gentiles. This paradox, clearly set out in Romans 11, could be summed up by saying: Israel has become what Adam is, so that Adam may become what Israel is.

18. Grundmann, 1oc. cit. 550.

19. J. D. G. Dunn, Jesus and the Spirit, SCM, London (1975) 259-65 and especially 323-4.

20. Against Dunn, ExpT 89 (1977-8) 175. 
We can therefore restate and develop a little the framework of thought we are postulating, in order to show the way forward in the debate between Stendahl and Käsemann. God's answer to the problem of Adam is the people of Abraham: but this people, being themselves sinful, fail in the task, and their anointed representative has to do the job solo. Since this job is the inauguration of the new humanity, the Messiah is the foundation for the world-wide (i.e. Jew-plusGentile) community, those who are justified by his death and resurrection according to the promise to Abraham.

This framework holds together God's plan for Israel and the church and his purpose in justifying the ungodly. All can be traced back to the Damascus Road vision: the fact that God has raised up a man crucified for blasphemous and Messianic claims vindicates those claims and, by doing so, delineates a new form of Messianism, namely, a crucified one (not, of course, that this form was totally new, as early apologetic was at pains to point out: it was, rather, different from current expectation). It is not the case that paul merely now knew the name of the Messiah, and could fit him into a pre-conceived scheme. The realisation that the Messiah is the crucified Jesus destroys and remakes all Jewish categories, because of the identification of the Messiah with his people. Damascus Road says to Paul: this is what God is doing with Israel, putting her to death in the flesh and bringing her alive in a resurrection body. That is why the vision of Christ is also the start of Paul's call to be the apostle to the Gentiles, to be the Jew entrusted with the creation of the worldwide people of God, Israel crucified and risen again. And because Israel is God's means of remaking mankind, Damascus Road says to Paul: this is what God is doing for man in general, providing, in Israel's representative, justification for the ungodly and life for the dead.

We must now bring the debate between stendahl and Käsemann into the light of this view of Paul. To Käsemann we must say that justification is indeed to be set in the context of salvation history: otherwise it becomes, as in the case of Bultmann, anthropology or unhistorical mysticism, both of which käsemann rightly rejects. This does not set the church over Christ, as he fears: indeed, since salvation history has the shape of the cross and resurrection, the crucified and risen 
Christ is the pattern, as well as the Lord, of history. For this reason salvation history can never be the comfortable pious community of 'good' people which Käsemann so dislikes. Salvation history cannot be triumphalistic, if it is to be true to itself. As the risen Lord is recognised by the mark of the nails, so the risen Israel must be known by its suffering, temptation, repentance and bearing of the cross. If the church is, in salvation historical terms, ecclesia catholica, the visible community of God's people, its cross-and-resurrection pattern demands that it be also ecclesia semper reformanda.

To Stendahl, on the other hand, it must be said that salvation history is not an end in itself, but God's way of saving people from sin, of remaking mankind as the eschatological people of God. Stendahl, like Albert Schweitzer, has made justification a 'subsidiary crater' in Paul's theology, and this the whole framework we have set out denies. An interesting exegetical point emerges here. Schweitzer set Romans 6-8 over against Ronans 1-4 as a different, and more fundamental, doctrine of salvation (the 'mystical' as opposed to the 'juridical'), and Stendahl has implied that Romans 9-11 takes precedence over Romans 1-4 (the 'historical' rather than the 'juridical'). But the three sections cannot be played off against each other in this fashion, and indeed any solution that shows how they cohere must have a strong prima facie claim against views which find them irreconcilable. This could be argued in detail,/21/ but one point must suffice here. In the course of Galatians 2,3 and 4 Paul uses material which is paralleled in Romans indiscriminately' throughout chs. 1-11; and in Galatians it is all mixed up together in one long argument. Justification, baptism into Christ and salvation history are all, it appears, inescapably correlated. To use an analogy, we are not dealing with different sets of cards, but with the same set of cards simply shuffled and redealt in different patterns. Stendahl, by failing to see this, has ignored large and important areas of Paul, not least the offence of the cross and the criticism of the Jews which Paul actually mounted, in his efforts to absolve Paul's contemporaries from the charges of being legalists and having bad consciences.

21. Cf. my forthcoming thesis on Romans. 
Our position, then, can incorporate the strengths of both parties while avoiding their weaknesses. We must, first, stress both the continuity of the church, with Israel and with itself, as an historical and visible community and the discontinuity which occurred on the cross and which challenges the church continually to reform itself under the word. The church is Israel but no longer according to the flesh, just as Jesus Christ is raised from the dead never to die again, and just as the Christian is truly human but no longer (in Paul's sense) 'in the flesh'. The church is Abraham's family, but now worldwide: missionary activity, from paul to the present day, is therefore part of the inevitable theological structure of the church./22/ Second, we must see justification by faith as a polemical doctrine, whose target is not the usual Iutheran one of 'nomism' or 'Menschenwerke', but the Pauline one of Jewish national pride. The way in which, for Paul, the Jews filled out the sin of Adam was not by using the law as a ladder of good works but by using it as a charter of national privilege. And this total critique of what I have called 'national righteousness' goes back, if we are to believe the gospels, to John the Baptist and to Jesus himself. God can give Abraham children from these stones: many will come from East and West and sit at table with Abraham, while the sons of the kingdom are cast out./23/ Justification by faith is a polemical doctrine because it declares that the way is open for all, Jew and Gentile alike, to enter the family of Abraham. Possession neither of the Torah nor of

22. Not forgetting the continuing mission to Jews, as set out in Rom. $11=11-24$. This must be maintained against stendahl $P J G$ 132. Stendahl has made an interesting addition to a footnote in the original article (PJG 84 n.9, cf. HTR 56 (1963) 204 n.9), acknowledging the force of Rom. 1l:llff. in this context. But (a) he also ignores Rom. 2:2529, another passage where Paul contrasts Jews and Gentile Christians, and (b) he does not allow this modification to affect his analysis of Romans 9-11 as a whole - as it would if thought through fully.

23. Mt. 3:9// Lk. 3:8: Mt. 8:11-12. 
circumcision is necessary for membership of the true Israel. It is not that faith is easier than lawkeeping: both are, for Paul, impossible without grace. Nor is it, despite the nineteenth-century idealism which still dogs our footsteps here, that faith is more 'spiritual': for Paul the law itself is 'spiritual'./24/ The significant point about faith is simply that, unlike the Torah, it is available world-wide: that is why, when God promised Abraham a world-wide family, it had to be on the basis of faith. This is the thrust of Romans 4 and Galatians 3. And all this, as Käsemann has rightly seen, is fundamentally Christological. The cross and resurrection of the Messiah, as themselves a revelation of the righteousness of the one God (Romans 3:21-31), are the key to the whole pattern, as well as the means of its revelation to Paul on the Damascus Road.

Stendahl, therefore, has drawn attention to material which protrudes awkwardly from the traditional view. But he has then made a new system out of only those protruding bits, ignoring the original - and not unimportant - framework. We need his new insights, but within a framework where they are at home with the rest of Paul. Käsemann's protest, while in many ways justified, needs to have its horizons widened, via the Christology which is its strength, to include God's purposes in history as the shape, content and raison d'être of justification itself.

But here a serious question emerges. Is it possible for a radical protestant to align.history and faith in this way at all? I want now to conclude this first (and longer) half of my lecture by examining the wider question of history and faith - the question of the relationship, in Paul, between faith and the Jesus of history.

It is by now customary to reject Bultmann's thesis, that 2 Corinthians 5:16 implies that Paul had no interest in the historical Jesus beyond the barest facts of his existence and death./25/ In fact, the verse if

24. Rom. $7: 14$.

25. Theology of the New Testament, SCM, London (1952) I, 238f.: compare C. K. Barrett, The Second Epistle to the Corinthians, A. \& C. Black, London (1973) $171 f$. 
anything gives support to our case, that Paul's Jewish ideas of 'the Messiah according to the flesh' had to be drastically re-assessed in the light of the death and resurrection of the Christ and the resultant new creation. But this exegesis of Bultmann's was merely symptomatic of a wider point, which has remained highly influential and which, I believe, runs quite counter to paul. It is this: that in order to preserve the doctrine of justification by faith in its Iutheran purity, as a theology of the Word and as a theologia crucis, faith must be cut off from history and must stand by itself. To base faith on history, this view says, makes faith into a work. Elevated into a principle, this divorce of faith and history has been regularly offered as an underlying vindication of the whole historical critical method itself./26/ But in fact this principle is not only untrue to paul. It proves too much: because (as we often see in its practitioners) instead of leading to an historical critical method worthy of the name it leads to an historical sceptical method, in which historical facts must not be knowable, lest anyone should attempt to base his faith on them and so cease to be a 'protestant'. At this point it could be argued that the method ceases to have any claim to the word 'historical' at all: it has to find 'myth' in the gospels (for instance), because only myth will do for its sort of faith. Historical facts imperil the doctrine of justification. But this is justification by doubt, not by faith: and faith is opposed to 'doubt' no less than to 'sight'. Of course faith must be prenared to walk in the dark: but being in the dark is not equivalent to having faith. And in fact, for Paul, justifying faith has clear historical facts as its object - facts whose denial is not faith but unbelief.

This has begun to be recognised in the work, for instance, of Professor Stanton, who has shown that Paul was much more interested in Jesus of Nazareth than has

26. See, e.g., G. Fbeling, word and Faith, SCM, London (1963) (ET of Wort und Glaube, J. C. B. Mohr (Paul Siebeck), Tübingen (1960)) 34-6, 54-6, 60: and compare Kasemann, PP $48 f$. 
often been thought./27/ It is also clear in the oftenrepeated central thesis of J. D. G. Dunn's most recent volume./28/ But I want here to draw attention to two further aspects of the same point.

The first (mentioned tantalizingly briefly by stanton /29/) is Paul's doctrine of the obedience of Jesus Christ. Paul never speaks of Jesus obeying the law (though he certainly did not imagine that Jesus had broken the law), but rather, in Philippians 2 and Romans 5 , of Jesus' obedience to the whole saving purpose of God. Not only did Jesus offer God the obedience which Adam had failed to offer: he offered God the obedience which Israel should have offered and had likewise failed in, obedience to the vocation of redemptive vicarious suffering for the sins of the world. This is the theology which, in Romans 5, ties together all the other strands of the epistle. Though Christ's 'act of obedience' clearly refers to his death in particular, the scope of Philippians 2:5-11 shows that it is wider, including the obedient and humble life which culminated on the cross. Here, at the heart of Paul's theology and as the object of faith, there stand historical events by which that faith, and the theology built around it, stand or fall. Jesus as Israel, Jesus as man, established the new people of God, the new humanity. In order to free the world from real, historical sin Jesus gave, according to Paul, real historical obedience to God.

27. G. N. Stanton, Jesus of Nazareth in New Testament Preaching, Cambridge University Press (1974) 86116.

28. J. D. G. Dunn, Unity and Diversity in the New Testament, SCM, London (1977), where (e.g. p. 369) the unifying element is said to be 'the unity between the historical Jesus and the exalted Christ'.

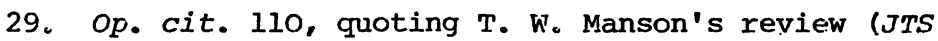
50 (1949) 206) of Bultmann's Theology. See too R. N. Longenecker, 'The Obedience of Christ in the Theology of the Early Church' in Reconciliation and Hope (L. I. Morris, Festschrift), ed. R. Banks, Paternoster, Exeter (1974) 142-52. The idea that Christ obeyed the law is, however, no part of our case: see below. 
The second area in which Pauline justifying faith is based on history is the resurrection of Jesus. For Paul in 1 Corinthians 15 it is crucial that this was an event in history, not in mythology or in meta-history or in the disciples' imagination or in some 'spiritualized' area otherwise outside the province of the scientific historian. It will not do to attempt to play off Paul against Luke here by maintaining that, while Luke spoke of Jesus' risen 'flesh', Paul wrote instead of the risen 'body'./30/ 'Flesh', for Paul, is a notoriously specialized term, whose absence in Paul's picture of the resurrection signifies not at all an idea of incorporeality but simply that in the new creation there is nothing opposed to God, no foothold for sin or corruption. The resurrection, again, is for Paul the beginning of the end, the first event of the great eschatological consummation, the inauguration of the sovereign rule of God in which at last God's intention at creation, and (as in Psalm 8). in Israel can be fulfilled, namely, the rule of the world through obedient man. It is very significant that in 1 Corinthians 15 too Jesus is described as the last Adam./31/ The resurrection means that the remaking of creation has begun at last: and the remaking will not be less real, nor less historical, than the first making. And since the Messiah represents Israel, there is as much continuity between Israel $B C$ and $A D$ as between Jesus on Good Friday and Jesus on Easter Sunday. What you do with the resurrection you do with the church - as is apparent from those theologians who take the easy way out and remove both from true historical existence. For Paul, then, Jesus' obedient life and death, and his vindication and resurrection on

30. Against Dunn, op. cit. 224.

31. In this Pauline picture of the Kingdom of God, God's sovereign rule exercised on the last days through his obedient last Adam, we may be justified in seeing a third, more subtle connection of Paul's faith with Jesus of Nazareth, this time in the area of his teaching. While Paul does not often quote Jesus' words, we might suggest that in Romans 5, Philippians 2 and 1 Corinthians 15 we have creative theological reflection (in the light of Calvary, Easter and Pentecost) on Jesus' teaching about the Kingdom of God and the Son of Man. Here at least is a possibility worth exploring further. 
the third day (if an actual event is not indicated, why would there be this stress on the date?) were facts upon which faith was to be built. If Christ is not raised, faith is in vain.

If this is so, the charge that basing faith on history turns faith into a work rebounds on its inventors. Faith, if anything, becomes a work when it is not based on history, when it is reduced to terms of selfunderstanding or when it becomes, in effect, its own object. The history of Jesus is the God-given context which, in grace, evokes faith and gives it its content. We must not be neo-Docetists any more than neoMarcionites. Jesus is not reducible to my experience of him, any more than the historical Israel of cod is reducible to our experience of community within it. such reductionism, laudable no doubt in its desire to promote living Christianity, instead of orthodoxy, and to stress the pro me of the gospel, owes far more to empiricism and idealism than it does to Paul. This shows up a false dichotomy that has existed far too long in pauline studies, the dichotony between the church as the people of God and the church as the body of Christ. Again there is time only to summarize: the church is the body of Christ in the same way that the Jews are the flesh of Christ. Jesus was identified with the people of God, the Jews, according to the flesh, and he died in the flesh. When he rose on Easter morning he rose as the representative of the church, no longer limited by Jewish flesh but in the resurrection body. That is why, as Pannenberg has stressed, the resurrection and the Gentile mission are inescapably correlated./32/ In this sense it is true to say that the church is the resurrection body of the Messiah, just as it is true to say that the Jews were the flesh of the Messiah. And the concept of the body of Christ thus carries within itself not only the overtones of charismatic and mutually $x \in$ sponsible community. It concentrates in one vivid metaphor, which is yet much more than a metaphor because of the Messiah's real identification with his feople, the Pauline pictures of the church as the nevr humanity, the true Israel, the

32. Cf., e.g., W. Pannenberg, Faith and Reality, Search Press, Ioncion (1977) 58-62. The argument of these pages also supports our wider thesis about faith and history. 
historical and visible people of God. Paul sets this out, I believe, in one long argument whose foundation is in Romans 9-11 and whose conclusion is Romans 12:5: we can trace it also through Galatians 3 and 1 Corinthians 10-12./33/ This is the point at which justification, salvation history and the idea of baptism into Christ, entry into the visible community of God's people, meet and merge. For Paul, the historical Jesus and the historical church are not antithetical to faith, but its close correlates. The Paul of history is also the apostle of faith, just as, for Paul, the Jesus of history is also the Christ of faith.

\section{The 'Real Paul' and the Imaginary Apostle}

I have deliberately devoted most of this study to exploring history and faith in Paul, and to drawing a new picture of Paul's theology which I believe does more justice to the texts than the usual one. I want now to turn to the other meaning of my ambiguous title, and to examine the real Paul in contrast with the imaginary apostle that the traditional understanding is always in danger of producing. In doing this I am, of course, conscious of all sorts of presuppositions and dangerous imaginations on my own part, and do not pretend to have solved all the problems and arrived at hard and indisputable historical facts. I simply want to mark out areas in which our traditional understanding of Paul seems to me to be at direct variance with the texts of the letters as they stand before us: and often this has been tacitly acknowledged when critics admit that they cannot see what Paul is driving at in a particular passage which simply refuses to fit into the regular view. I shall stick to the epistles, though I believe there would be striking results also if this understanding of Paul were applied to Acts $13-28$ as well.

33. For detailed arguments, see my forthcoming thesis. This view also contributes positively to the debate about the Body of Christ as outlined in Moule, op. cit. 69-89, and holds together in particular the strong points of J.A. T. Robinson, The Body, SCM, Iondon (1952) and R. H. Gundry, Sōma in Biblical Theology, CUP, Cambridge (1976), while avoiding their respective weaknesses. 
There is one particular misunderstanding of Paul which has dogged the footsteps of Pauline studies, particularly (though by no means exclusively) in the Iutheran tradition. Here I am no longer so much out on a limb since the publication of Charlotte Klein's small book, Anti-Judaism in Christian Theology/34/ and E. P. Sanders' much larger Paul and Palestinian Judaism./35/ In fact, what both are saying about Judaism supports strongly if indirectly the position I am arguing throughout this lecture, though ironically neither of them - despite Sanders' intentions - see the relevance of their thesis for Pauline studies.

My case here is simply stater: the tradition of Pauline interpretation has manufactured a false Paul by manufacturing a false Judaism for him to oppose. Nor, it appears, is this a chance mistake. It seems to be a subtle variation on the theme of seeing one's own reflection at the bottom of a deep well. That activity, so well known from the history of gospel criticism, is comparatively easy to recognise. What we are now faced with in New Testament criticism is a method that claims to be talking about Paul's (or Jesus', or Mark's, or Matthew's) opponents, and in reality is seeing, at the bottom of the same muddy well, the reflection of its own opponents. That is why I am at once suspicious when someone standing foursquare in the Lutheran tradition tells me that Matthew's chief purpose was to fend off 'nomism' on the one hand and 'enthusiasm' on the other.

34. SPCK, London (1977), ET of Theologie und AntiJudaismus, Chr. Kaiser Verlag, München. See too Stendahl's remarks in PJG 132f., and the wideranging analysis of anti-semitism in $\mathrm{H}$. Küng, The Church, ET of Die Kirche, Hexder, Frieburg-BasleVienna (1969), Search Press, London (1968) 132-8: note especially Hegel's view of Judaism as the manifestation of the evil principle (Küng, 136). In view of Rom. 11, it would be better to speak of 'the hidden Adam within Israel' than of 'the hidden Jew in all of us', with all its overtones of just that inverted theological snobbery which Rom. 1l:llff. was written to counteract.

35. SCM, London (1977). 
I have met those categories before, and they belong not to the first century but to the sixteenth, and to Luther's double battle against Rome and the radical reformers. The same misgivings arise when a generation that hates triumphalism and is suspicious of miracles declares that Mark and John found tales of a divine miracle-working hero, and that instead of consigning such dangerous stuff to the rubbish-heap, they went over them, carefully superimposing a theologla crucis, with such skill that nc-one can agree on the breaks in the material. But such misgivings are hard to substantiate. We have no record of Matthew's community except Matthew, nor of Mark's sources except Mark. With Paul and his opponents it is quite different.

Though the problem of dating Jewish sources is of course notoriously difficult, we have in the Rabbinic literature, the Targums, the Scrolls and the Apocalyptic literature a broad and varied picture of the many-sided Judaism which, in the widest sense, formed Paul's milieu. Those who are experts in these fields (i.e. those who read the literature for its own sake instead of merely combing it for parallels to the New Testament) have recently been saying increasingly clearly that the real Judaism was not a religion of legalistic worksrighteousness. G. F. Moore said this fifty years ago, and nobody listened./36/ Sanders, Schoeps/37/ and Klein have now said it in England, Germany and North America, and unless we are to bury our heads in the sand we must pay attention. Sanders in particular has documented the way in which the traditional view of Judaism was set out by Weber, Schürer and Bousset, enshrined in StrackBillerbeck, and repeated by scholars who did not check back behind these assumed infallible guides./38/ In fact,

36. G. F. Moore, 'Christian Writers on Judaism', HTR 14 (1921) 197-254: cf. Sanders, op. cit. 33-59.

37. H.-J. Schoeps, Paul: The Theology of the Apostle in the Light of Jewish Religious History (ET of Paulus ... J. C. B. Mohr (Paul Siebeck), Tübingen (1959)), Lutterworth, London (1961).

38. Sanders, 10c. cit. 
we are told, Judaism, so far from being a religion of works, is based on a clear understanding of grace, the grace that chose Israel in the first place to be a special people. Good works are simply gratitude, and demonstrate that one is faithful to the covenant - a sort of primitive version of the tertius usus legis. Where, then, did the idea of a works-righteousness come from? Sanders has a ready answer, backed up by long and patient argument: 'We have here the retrojection of the Protestant-Catholic debate into ancient history, with Judaism taking the role of Catholicism and Christianity the role of Lutheranism'./39/ This appears, to take but one example, in the often-repeated and massively anachronistic assertion that the Pharisees or the Rabbis held a doctrine of 'works of supererogation'./40/ We might supplement this presupposition, of the ProtestantCatholic debate, with three variations. Baur and the German idealists were very ready to cast Paul and the Jews in the roles of pure spirit and outward religion. Kümmel, Bultmann and their followers have seen in them the contrast of authentic existence and the anxious struggle for self-understanding and self-justification. English evangelicals have tended to see the Jews as the establishment figures, the liberal or high-church bishops and theologians, with Paul as the evangelical underdog who wins through in the end, while (of course) keeping his nose clean from charismatic excesses within his own camp.

The result of the traditional, and false, picture of Judaism has been, then, the manufacture of an imaginary apostle, attenuated and demythologized to suit the limited needs and desires of certain periods and groups, an apostle who must be made to oppose sixteenth- or twentieth-century enemies of which the paul of history was unaware. And exegesis suffers directly as a result. We have the apostle of existentialism, experiencing authentic existence incompatible with the struggles faced

39. Op. cit. 57. From this point of view, the debate between Paul and James looks more like a debate between Paul, James and Judaism on the one hand and Lutheranism on the other.

40. Cf. Sanders, op. cit. 48. 
by the Paul of history in Romans 7 or Galatians 5./41/ We have the apostle who opposed 'triumphalism', while the Paul of Colossians and 2 Corinthians triumphantly leads enemies captive to the gospel. We have the apostle who abolished the law as a dead letter, to be contrasted with the Paul who, in Romans 3:31, expressly and consistently denies doing any such thing./42/ We have the apostle who opposed 'ritualism' in Galatians, and who therefore could not have substituted baptism for circumcision:/43/ whereas 'ritualism' is in fact a blunt modern tool, quite unfitted for the analysis of first century concepts. We have, in short, as a result of a projection of reformation and modern ideas into the world of Paul, an apostle of faith, or at least of imagination, who reveals more about his inventors than about the paul of history.

How then did the real Paul face up to the real Judaism of his day? Here, sadly, the advocates of a new view of Judaism let us down. Schoeps, on the one hand, having exonerated Judaism from the traditional charge of worksrighteousness, preserves the usual view of Paul, and consequently accuses him of attacking only a debased and untypical form of Judaism. Sanders, on the other hand, seems at a loss to know how to cope with this problem, and concludes rather lamely that Paul rejected Judaism simply because it was not Christianity, and because he had found salvation in Christ./44/ Neither of these views are at all satisfactory, any more than the idea that Paul as a Rabbi had a clear picture of the Messianic age, including the abolition of the law, and that he simily fitted Jesus into this picture./45/

41. Cf. e.g., R. Bultmann, 'Romans 7 and the Anthropology of Paul' in Existence and Faith, Fontana, London (1964) 173-85. For the contrary view cf. e.g., J. D. G. Dunn in TZ 31 (1975) 25773.

42. Compare the confusing account in J. W. Drane, Paul, Lihertine or Legalist?, SPCK, London (1975).

43. Dunn, Unity and Diversity, 159f.

44. Sanders, op. cit. 549-52.

45. For this view and its weaknesses see the discussion in Sanders, op. cit. 476-82. 
In fact, as we have already begun to show, Paul mounts a detailed and sensitive critique of Judaism as its advocates present it. The key passages are Romans 2: 17-29, 3:27-31, 9:30-10:13, Galatians 2-4 and Philippians 3:2-11. Space forbids a detailed study of all five passages, and I therefore restrict myself to two.

There are four brief points to be made about Romans 2: 17-29. First, Paul's basic charge against the Jews is that of boasting. Nor is this the boast of the legalist tout simple. The Jew boasts in God (v. 17), claiming God as the God of the Jews and not the Gentiles. This meaning is clear from 3:27ff. The Jew also boasts in the law ( $v, 23)$ : not, that is, because he keeps it and so has earned salvation, but because his possession of the law marks him out as a member of the chosen people. Second, Paul's accusations are not against legalism, but against sin, the breaking of the law. This (thirdly) leaves the law itself undamaged: it remains, as in ch. 7, God's law, containing the form of knowledge and truth. Paul has not a word to say against the law itself, but only against its abuse - and its abuse is not legalism but 'national righteousness', the attempt to use the fact that God has entrusted the Jews with his oracles (compare $3: 2$ ) as a foundation for permanent and automatic Jewish privilege. Again, 3:27-31 undergird all these points. Fourthly, Paul's attack on Jewish trust in the law and circumcision as badges of national privilege does not abolish the idea of the 'true circumcision' which keeps the law from the heart. In language rich with 'new covenant' significance, Paul outlines here his theology of the church as the true Israel, the people of God. For those who are interested in how Paul was read in the second century, it should be noted that this passage has very close links with Justin's dialogue with Trypho./46/

Romans 2:17-29 is a somewhat neglected passage. The same could not be said of 9:30-10:13: here, in fact, the same position is taken up, with detail appropriate to this section of Paul's overall argument. The traditional view has been to maintain that Paul attacked Israel for following the law, showed that the law was abolished by

46. See particularly chs. 11, 16, 18f., 23f., 28, 43, 92, 113f. 
Christ, and set up a new way of salvation, that of faith./47/ This Iutheran view has been subjected to damaging criticism from the Reformed standpoint, and Cranfield in particular has shown that 9:30-33 in fact vindicates the law while showing that Israel has not attained to it./48/ The Reformed view, however, does not itself do full justice to the text either. Israel's fault is not 'legalism' as such, but 'national righteousness'. This appears particularly from 10:3-4. Israel, being ignorant of God's righteousness, and

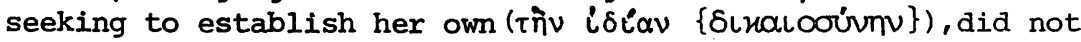
submit to God's righteousness: for Christ is the end of the law, so that everyone who believes, Jew and Gentile alike ( $\pi \alpha \nu \tau i$ is to be emphasized as the contrast to $\tau$ nnv ( $\delta(\alpha \nu)$ may be justified. We may compare vv. 11-13. The Lutheran attack on the law is misplaced; and, I believe, the Reformed attempt to rescue the law overplays its hand. Paul dces not say that Christ fulfills the law. $\mathrm{He}$ is no more a legalist than anyone else is. The fulfilling of the law comes, as in 2:25-29, within the context of the people of God, the true Israel, who by the Spirit make the baptismal profession of faith (10: 6-10). As we would find in Galatians and Philippians also, Paul vindicates the law, demontrates how its abuse as a charter of national privilege is done away by the rejected and crucified Messiah (hence the stone of stumbling in 9:33), and establishes the worldwide church as the true people of the Messiah, the spirit-filled visible baptised community.

Paul's criticism of Judaism, then, was on target, as can be seen from the account of Jewish attitudes to the Gentiles given by Sanders./49/ The polemic against the

47. Cf. e.g., W. Sanday and A. C. Headlam, A Critical and Exegetical Commentary on the Epistle to the Romans, T. \& T. Clark, Edinburgh (19025) 275-92.

48. C. E. B. Cranfield, 'Some Notes on Romans 9:30-33' in Jesus und Paulus. Festschrift für W. G. Kümmel zum 70. Geburtstag, ed. E. E. Ellis and E. Grässer, Vandenhoek and Ruprecht, Göttingen (1975) 35-43.

49. Op. cit., 147-182, 206-212: see especially 180, 211. 
law is to be seen in this context, and emphatically not in the sixteenth- and twentieth-century categories of 'legalism' or 'nomism'. It would be interesting to show in detail how, in their different ways, Baur, Wrede and Schweitzer felt after this solution but were diverted from following it through: here we can only summarize. Baur saw the critique of the law as being against Jewish particularism, though he saw it as JewishChristian particularism only./50/ Wrede thought Paul's view of the end of the law dependent in part on the needs of the Gentile mission, though he (like Davies, later) thought that Paul had, in his Rabbinic days, a fully-blown picture of the Messiah, into which he simply fitted Jesus./51/ Schweitzer, too, related Paul's view of the law to the worldwide scope of the gospel, though he did not make this a driving force in his arguments. /52/ In fact, as we have seen, Paul's critique of the law forms the spearhead of his doctrine of justification, which is itself (to stretch the metaphor in a Pauline fashion) the spearhead of the doctrine of salvation history. The critique of the law, that is to say, follows from the rejection of Israel: and all is once again based on the crucified and risen Messiah, and on the righteousnesss of the one God.revealed in him. Christ is the end of the law, so that everyone who believes (and not merely Jews) may be justified - and may then, as members of the eschatological but still historical Israel, have the law written on their hearts by the spirit. This is the message of the historical Paul, by which we must correct the teaching of the imaginary apostle.

50. F. C. Baur, Paul the Apostle of Jesus Christ, ET, Williams and Norgate, London and Edinburgh, 1873-5.

51. W. Wrede, Paul, ET, Philip Green, Iondon (1907). Compare W. D. Davies, Paul and Rabbinic Judaism, SPCK, Iondon (1955).

52. A. Schweitzer, Paul and His Interpreters, ET, A. \& C. Black, Iondon (1912): see especially p. 246. The same position is worked out in The Mysticism of Paul the Apostle, ET, A. \& C. Black, London (1931) 177-204. 
It is high time to draw the threads of this lecture together, which I propose to do by asking: what categories is it appropriate to use in investigating Paul's theology? It is quite unsatisfactory, as Schweitzer noted with some scorn, to produce merely an unrelated string of Pauline 1oci./53/ How are we to show the integration and coherence of his thought? Jewish categories by themselves will not do: not only did Paul explicitly reject them, but we have also seen that the attempts to turn Paul into a good (or even a bad) Rabbi have not been markedly successful, however important they may have been in alerting us to the presence of Jewish elements in his thought. At the same time, we have set all sorts of question-marks beside the traditional Lutheran and existentialist understanding of Paul, so that as well as the doubts which are being raised more and more by Hengel and others about the division of Jewish and Hellenistic Christianity (itself often a mere mythologizing of language differences into unwarranted geographical or chronological schemes), /54/ we now have good reason to doubt the scheme which sets 'enthusiasm' on one side of the golden mean and Frühkatholizismus on the other. I believe that J. D. G. Dunn has implicitly destroyed this scheme, even though it continues to dominate his writings, by demonstrating with great skill that Luke was both an 'enthusiast' and an 'early catholic'./55/ If both categories fit the same writer so well, neither can be of any great relevance to New Testament criticism, since it is of the essence of both categories that they exclude each other. In fact, Dunn recognises in a footnote the presence in much of the New Testament of the idea of the continuity between Israel and the church:/56/ what I have tried to do in this lecture is to explore that idea in Paul at least, and I believe that it would stand not just as a parallel to his continility of Jesus of Nazareth and the exalted Lord but actuilly as the necessary consequence

53. Paul, 33.

54. Cf., e.g., M. Hengel, The Son of God, particularly 57-83, and the literature there cited; I. H. Marshall, 'Palestinian and Hellenistic Christianity: Some Critical Comments', NTS 19 (1972-3) 271-87.

55. Dunn, Unity and Diversity, 356-8.

56. Ibid., 398 n.26. 
of that continuity. And the view I have presented of Paul's church is the eschatological Israel - a concept which easily includes within itself the gift and life of the Spirit on the one hand and the historical and organizational church on the other.

But to admit that is to ask for a new set of categories altogether, that will allow fully for the correlation of justification and salvation history, based upon the Christology of the crucified and risen Messiah, which we have been exploring. I believe that Paul himself offers us such categories. To begin with, he offers the old Testament, interpreted in the light of the death and resurrection of Jesus the Messiah. This does not mean the old Testament as a helpful collection of proof texts to be called in if and only if they fit what Paul wants to say on other grounds, a book to be treated as servant rather than master./57/ If it did, the concept would collapse from sheer lack of logic, since an authority would be at the same time claimed for, and denied to, the old Testament. Rather, it means that the old Testament is seen by Paul as the kook of the people of God, and like the people of God this book must die and be raised. Therefore (to take an obvious example), the food laws, relevant to the time when Israel was one geographical and physical nation, are not relevant now that Israel has died and been raised as the worldwide people of God. On the other hand, much of the law, as quoted in Romans 13, is equally relevant: there is the continuity of resurrection as well as the discontinuity of death.

Paul, then, offers us the old Testament as the book of the people of the Messiah, to be interpreted as such. He offers us, as we have seen, the Messiah as a Jew

57. Against B. Lindars, 'The Place of the Old Testament in the Formation of New Testament Theology: Prolegomena', NTS 23 (1976-7), 59-66. Lindars' suming up, likening Jesus' demoting of the scriptures from master to servant to Jesus' changing of the basis of religion from law to grace (p. 66), shows that a new view of law and grace such as this lecture has worked out is justified in seeking a parallel new view of oT hermeneutics. 
according to the flesh and as the risen Lord of all, Jew and Gentile alike - in other words, he offers us the Messiah not just as an individual but as the representative of his people, both his people according to the flesh and his new covenant people, his eschatological, worldwide, Spirit-filled Israel. With categories like that, the standard divisions, and particularly the concept of Early Catholicism, stand out as being anachronistic, arbitrary and misleading. It is not just, as Dunn admits, that the categories are loose and overlapping though more or less right,/58/ as though one were to play squash with a tennis or badminton racquet. It is simply that these are the wrong categories for analysing the material at all. It is more like trying to play squash with a golf club.

My view of Paul can be summarized in a paraphrase of Romans 1:3-5. Paul, having been born a Jew according to the flesh, became a true Jew, a son of God, according to the Spirit of holiness, by the resurrection from the dead, and on the same basis was commissioned as the apostle to the Gentiles, holding together in himself the triple resurrection of Jesus, of Israel, and of his own baptism. Paul's life and thought flow consistently from his vision on the Damascus Road, and salvation-history and justification by faith take their proper places as inescapable partners within his Christology, which is itself based on the doctrine of God, the one true God of Jew and Gentile alike, the God who reveals his righteousness in the gospel of his son. The categories with which we are to understand Paul, and for that matter the whole New Testament, are not the thin, tired and anachronistic ones of Lutheran polemic. They are the ones given to us by the Paul of history himself. of course there will always be problems and arguments over details and passages and words. I would not pretend to have solved all the problems at a stroke. But at least we have here a framework within which Paul's ideas are not played off against each other, nor cheaply reconciled, but rather integrated and mutually illuminating. The real Paul, the Paul of the letters, must continue to provide the critique of the modernized apostle. His view of history and of faith, in which the two are not divorced but held inescapably together, must

58. Op. cit. $236 f$. 
inform our exegesis of him at every point. And, therefore, this programme can only be carried out in a truly Pauline fashion, by holding together a true historical method and the perspective of faith, by refusing to lapse into historical scepticism on the one hand or into unhistorical, or unthinking, pietism on the other. If controversy is the breath of life to the theologian, in England as well as in Germany, that may be because it is the necessary means by which the balance is to be kept, by which the believing community is to remind itself that it is also the historical church, and, conversely, by which the visible church may live under the word and by the spirit - the means by which ecclesia catholica is to remain ecclesia semper reformanda. 